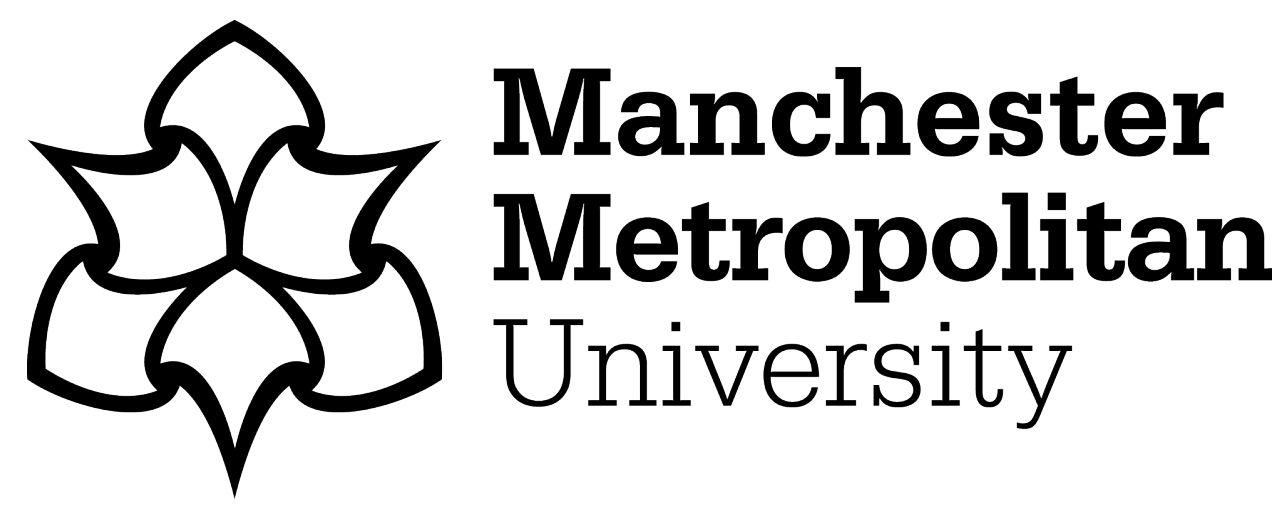

Ward, SJ and Hines, A (2018) The Demise of the Members' Association Ownership Model in German Professional Football. Managing Sport and Leisure, 22 (5). pp. 358-373. ISSN 2375-0472

Downloaded from: https://e-space.mmu.ac.uk/620750/

Version: Accepted Version

Publisher: Taylor \& Francis

DOI: https://doi.org/10.1080/23750472.2018.1451359

Please cite the published version 


\section{The Demise of the Members' Association Ownership Model in German Professional Football}

German professional football clubs have operated under a members' association governance structure for several decades. Pressure to change the members' association governance model in Germany intensified during the late 1990s and as a consequence, governance rulings were relaxed to allow private investment into football clubs. Utilising a case study approach, this article provides a case study insight into Hamburger SV FC, who unlike their counterparts, voted to remain as a members' association until 2014. The findings highlighted that the governance model helped instil democratic decision-making and influenced the club to favour long term planning over a short-termist approach. The club faced many challenges to their chosen governance structure due to the growing perception among members that it was hindering the club's ability to compete on the field. This article contributes to the growing body of literature focusing on the implications a football club's ownership structure has on performance.

\section{Keywords}

Members' associations, mutuality, nonprofit governance, german football, stakeowners 


\section{Ownership Structures in German Football}

Prior to 1998, German football clubs were structured as registered members' associations, commonly known as an eingetragener Verein (e.V.). Private ownership of a football club was not allowed under any circumstance. Members' associations are nonprofit organisations mutually owned by their members and managed by representatives elected by these members. Members' associations are deeply rooted in German society, considered socially valuable and are a prevalent business model across the country. According to German law, members' associations must operate under a strongly focused constitution towards meeting the sporting needs of the club. All capital raised by the members' association, is required by law, to be reinvested back into the business to maximise sporting success. Members' associations within professional football came under widespread criticism in the late 1990's due to the perception this business model hindered the clubs' competitive advantage (Czarnitzki \& Stadtmann, 2002; Dietl \& Franck, 2007b; Franck, 1999, 2000; Littkemann et al., 2003; Weiler, 2007). Systemic pressure for governance changes began to build momentum from within the profession towards the German Football Association (DFB) to reconsider and evaluate the ownership rulings. These calls stemmed from the on-going lack of on-pitch success within international competitions (especially the Champions League) and the increased commercialisation of football in Europe (Franck \& Dietl, 2007; Lago, et al., 2006). German football, at the time, were also experiencing serious financial problems with professional football clubs competing in the lower leagues and especially clubs from the former East German leagues (Franck, 2010; Wagner, 1999; Pilz et al., 2006). Consequently, due to this sustained period of systemic pressure, the DFB voted in favour to change the existing current governance structures from October 1998, with the introduction of the ' $50+1$ ' ruling. 
Professional football clubs were able to convert their football teams into public or private limited companies. In doing so, football clubs were required to ensure that the parent club owned at least $50 \%$, plus one additional share, of the football company in order to protect the member's majority holding of voting rights (Franck \& Muller, 1998; Wilkesmann \& Blutner, 2002). This substantial shift in their governance structures became arguably, the catalyst for German football clubs, to be viewed upon, as medium sized companies rather than nonprofit voluntary sports clubs (Lammert, et al., 2009; Dimitropoulos \& Tsagkanos, 2012). There are now several forms of governance structures found in German football, as outlined in detail in Table 1 (Franck, 2010).

Table 1 - Types of Ownership Structures in German Professional Football

\begin{tabular}{|c|c|}
\hline Ownership Structure Type & Governance Type \\
\hline $\begin{array}{l}\text { Gesellschaft mit beschraenkter haftung } \\
\text { (GmbH)-Private Limited Liability Company }\end{array}$ & $\begin{array}{l}\text { GmbH stands for Gesellschaft mit beschränkter } \\
\text { Haftung, which means a 'company with limited } \\
\text { liability'. GmbH companies are incorporated and, } \\
\text { as such, are legal entities unto themselves. These } \\
\text { companies must have a minimum of two partners } \\
\text { and may be, but do not have to be, owned by a } \\
\text { public company. }\end{array}$ \\
\hline $\begin{array}{l}\text { GmbH \& Co KGaA \& GmbH \& Co KG- } \\
\text { combination of a limited company with a } \\
\text { Kommanditgesellschaft } \quad \text { (KG) (limited } \\
\text { partnership) or a Kommanditgesellschaft auf } \\
\text { Aktien (aA) (stock company). }\end{array}$ & $\begin{array}{l}\text { The GmbH \& Co. KGaA is a partnership limited } \\
\text { by shares }(\mathrm{KGaA}) \text {, whose general partner is a } \\
\text { limited liability }(\mathrm{GmbH}) \text {. This hybrid form allows } \\
\text { the liability of the limited partnership to be limited } \\
\text { to the assets of the GmbH, without having to give } \\
\text { up the legal form of the limited partnership on } \\
\text { shares. The limited partners this company } \\
\text { continue to be the limited partners of the KGaA. }\end{array}$ \\
\hline
\end{tabular}




\begin{tabular}{|l|l|}
\hline $\begin{array}{l}\text { Aktiengesellschaft (AG) - Joint Stock } \\
\text { Companies or Companies limited by shares }\end{array}$ & $\begin{array}{l}\text { Aktiengesellschaft (AG) is a German term for a } \\
\text { public limited company (an equivalent to an } \\
\text { English PLC). This is a company whose shares } \\
\text { are offered to the general public and traded on a } \\
\text { public stock exchange, and whose shareholders' } \\
\text { liability is limited to their investment. The } \\
\text { shareholders are not responsible for the company's } \\
\text { debts, and their personal assets are protected in } \\
\text { case the company becomes insolvent. }\end{array}$ \\
\hline Eingetragener Verein (e.V) & $\begin{array}{l}\text { A legal status for a registered voluntary } \\
\text { association in Germany. While any group may be } \\
\text { called a Verein, registration as eingetragener } \\
\text { Verein holds many legal benefits because a } \\
\text { registered association may legally function as a } \\
\text { corporate body (juridical person) rather than just a } \\
\text { group of individuals. The legal status must be } \\
\text { mentioned in the name as well. }\end{array}$ \\
\hline
\end{tabular}

There are some exceptions to the ruling in relation to cases where a person or company has substantially funded a club for a continuous period of twenty years or more. In this instance, it is possible for that person or company to own a controlling stake in the club. This exception most notably applies to Bayer 04 Leverkusen (owned by the pharmaceuticals company Bayer), and VfL Wolfsburg (owned by automobile manufacturer Volkswagen).

The DFB have come into repeated criticism since the introduction of the ' $50+1$ ' rule, with Martin Kind, the President of Hannover 96, being one of the most vocal. In 2009, a further motion was put forward to the DFB to abolish the ' $50+1$ ' rule completely with claims the rule was in breach of EU competition law,. However, this motion was overwhelmingly rejected, with 32 out of the 36 clubs voting against the proposal. It is clear that the DFB are remaining in favour of the ' $50+1$ ' ruling for the foreseeable future. In the meantime, the debate will 
continue over the notable impact differing governance structures can have on a football club's financial performance (Acero, et al., 2017; Franck, 2010; Ziebs, 2004; Vidovich \& Currie, 2012; Wilson et al., 2013). Furthermore, there continues to be conflicting viewpoints in the extanct literature about whether differing types of governance structures can hinder or benefit 'on-pitch' success (Callen, et al., 2010; Dietl \& Franck, 2008; Enjolras, 2009). There also remains an on-going debate as to whether a non-profit is more conducive to achieving inclusivity, stakeholder involvement and improved sustainability of a football club (Balduck, et al., 2010; Hassan \& Hamil, 2010; Ward, et al., 2012). To fully understand the implications of operating under a mutual governance structure, the next section provides a critique of the literature pertaining to mutuality in an operational and management context.

\section{Mutual Governance Model}

Puyvelde, et al., (2012) states that mutually formed businesses who make stakeholder groups their owners can form and manage their business strategy directly towards fulfilling stakeholder interests. Furthermore, mutually owned businesses geared towards upholding the core cooperative values at the heart of their strategy routinely state their objectives to be for the benefit of the wider community. Reid and Turbide (2011) state that one of the main advantages to increased stakeholder involvement is that they encourage longer-term strategies in order to improve performance. Wheeler and Sillanpaa (1997) suggest that there is evidence proving that businesses, which concentrate on fulfilling the long-term interests of their key stakeholders, are more likely to succeed compared with businesses focused on fulfilling short-term shareholder interests. Hutton (2007:284) has argued that 'since the 1970s there has been a sharp rise in the atrophy of regulation, and short-termism in business strategy'. He argues that this rise has resulted in the production of a corporate governance regime that strongly favours shareholder value, short-termism and a preference to hostile take-overs. 
Puyvelde, et al., (2012) claim that one of the main advantages of a mutually owned business is the primary focus on becoming community beneficial. This commitment to the community ensures all decisions taken by the board are in the best interests of this key external stakeholder. Anheier, et al., (2003b) states that democracy is one of the main benefits of mutuality due to the equitable process of becoming a member and the lack of emphasis on voting rights and financial input. Another advantage quoted in the extant literature stemming from a democratic ownership structure is that of promoting citizenship (Pergola \& Joseph, 2011; Tschirhart, 2006). Becoming a member within a democratically owned business provides the ability to receive information and influence decision making by applying the one member one-vote system and attending and speaking at meetings. Perilleux, et al., (2012) highlights that the key difference between a mutually owned company and an investor owned one is the pursuit of long term planning over short termism. Fama and Jensen (1983) claim that this difference can be contributed to the investor owned companies focus on achieving tangible and quick results to satisfy the business's share-price, dividends, profitability and the pursuit of senior executives to receive their bonuses. These are experiences not encountered by board members involved in making decisions within a nonprofit organisation. Instead, nonprofit board members are able to and must, in accordance to their constitution, make decisions that are based on serving the organisation's community (Brown, et al., 2011). These decisions manifest themselves in ensuring that current members' interests are fully met and, more importantly, are sustainable in order for the business to continue to serve future generations (Esteve, et al., 2011; Reid \& Turbide, 2011). Many of these points resonate with the issues encountered by fans and their football club where they have become 'psychological' owners via the members' association model.

However, there are disadvantages to nonprofit organisations with the most relevant one being the lack of any residual claimants. The 'residual claimant' refers to the economic agent who 
has the sole remaining claim on an organisation's net cash flows, i.e. after the deduction of precedent agents' claims, and therefore also bears the residual risk. Residual risk is defined in this context as the risk associated with differences between the stochastic inflows of assets into the organisation and precedent agents' claims on the organisation's cash flows. Precedent agents' claims on an organisation's cash flows can consist of e.g. employees' salaries, creditors' interest or the government's taxes (Fama \& Jensen, 1983). Consequently, it can lead to nonprofit organisations becoming less efficient than their for-profit competitors (Barbetta, et al., 2001). Steinberg (2010) adds that the presence of multiple principals (owners) with different objectives hinders the potential to resolve questions of nonprofit accountability. Nonprofit organisations can encounter problems with people management due to the individual lacking the right expertise or skillset, high turnover of volunteers within the business or employees not being able to complete every task due to being overworked. Leete (2000) states that uncompetitive wages offered by nonprofit organisations can also hinder employee turnover and engagement. Another disadvantage of a non-profit organisation is the ability to foster active participation of board directors to their main roles and responsibilities (Brown, et al., 2011; McDonald \& Sherry, 2010). Active participation by directors within nonprofit organisations can at times be diluted if the individual has other business interests outside of the organisation i.e., a full time job or their own business. In addition, some directors who have recently retired need to find the balance between work and private life especially as the roles are unpaid. Finally, Perilleux, et al., (2012) from their research into the ability of different structured organisations to source finance into the business conclude that cooperative firms are the least successful. These findings are mainly attributed to the fact that private investors are reluctant to invest in a cooperative due to the lack of voting rights their investment brings. This final point is arguably one of the main concerns within members' associations in football - Who owns the club? Who are the main shareholders?; and Who is accountable for ensuring sustainable revenue streams 
to the club? One of the main governance theories associated with the mutual governance model is the stakeholder theory approach, which is discussed in more detail next.

\section{Stakeholder Theory}

Stakeholder theory is widely used to explore sport organisations and is incorporated into work by Ferkins and Shilbury (2010) on non-profit sport boards. Cornforth (2003:8) states that 'the main function of the board is to maintain good relations with key external stakeholders in order to ensure the flow of resources'. This leads to the use of stakeholder theory to help explain this function. In particular, stakeholder theory explores the relationship between socio-political stakeholders such as organisations and local government and communities (Babiak \& Willem 2017; Jensen \& Meckling, 1976; Hill \& Jones, 1992). This developed from seminal work by Freeman (1984) who classified stakeholders as any person, group or organisation that affects and or is affected by an organisation's decisions. In her critique of stakeholder theory, Sternberg (1997) highlighted how the concept of stakeholders has developed over time, from people who the organisation have a stake in, to people that have a stake in an organisation. Murdock (2004) identifies the importance of exploring the nature of the relationship, how close the relationship is and whether the organisation influences the stakeholder or vice versa.

Further are the challenges created by the complex nature of multiple stakeholders having differing interests and goals (Agrawal \& Knoeber, 1996). Managing differing interests and goals are of critical importance due to the emphasis placed on shared goals, values and outcomes (Coalter, 2013; Harris \& Houlihan, 2016). Shared goals, values and outcomes were also found in research by Ferkins and Shilbury (2010:236) who highlight 'the issue of stakeholder representation and the extent to which the board assimilates the views of individuals and groups affected by the work of the organisation'. In other research, they highlight the importance of reciprocity and responsibility relative to the notion of the stake 
owner i.e. loyal stakeholders with a genuine stake, and that applying this to the nonprofit sport organisation setting could enhance capability (Ferkins \& Shilbury, 2015; Senaux, 2008).

The concept of inclusivity with external stakeholders to the organisation originated from stakeholder theory and indicated that nonprofit boards should make a concerted effort to work towards the best interests of their key external stakeholders (Brown, 2002; Weitzner \& Peridis, 2011). Brown (2002) states that a lack of inclusivity can result in the board misinterpreting the needs of their constituents and can result in the implementation of irrelevant organisational policies. Instead, nonprofit boards should view an inclusive approach within their organisation as critical for successfully engaging their constituents. However, several academics have recognised that due to the wide range of stakeholders who engage with a nonprofit organisation, the board have a difficult task in identifying common ground within a complex and diverse range of interests (Freeman, 1984; Herman and Renz, 2008). Brown (2002) states that a nonprofit board needs to implement systems in order to manage and evaluate their external stakeholders' requirements and provide the ability to encourage a continuous communication flow. Brown (2002) argues that if these policies and procedures are effective then a nonprofit organisation will benefit from an inclusive board.

\section{Research Aim}

Two specific research objectives were set:-

(a) To critically examine a members' association's governance practices within German football.

(b) To critically evaluate the implications to a football club operating as a members' association.

\section{Case Study Choice}


The case choice for this research was Hamburger SV football club (HSV). Despite governance law changes in 1998 , effectively allowing German football clubs to reduce their stake to $51 \%$ in order to attract private investment, HSV's members voted categorically to not follow suit. Instead, HSV remained 100\% member owned for a further sixteen years despite several challenges, from both internal and external stakeholders, to reconsider their governance structure. However, in early 2014, HSV came under intense scrutiny, once more, to reduce their stake in the club and allow private investors to become shareholders. Following, two seasons of poor results and close relegation battles, members voted overwhelmingly for $24.9 \%$ of the club to be sold. HSV's case study was deemed to be instrumental to provide a qualitative insight into the members' association business model of a football club. It is also one of the first qualitative case studies covering German football to be published in English.

\section{Case Study Approach}

Case studies provide an analysis of context and processes which illuminate the theoretical issues being studied (Hines, 2018). Eisenhardt (2007) notes that case study research allows for exploration of an under-theorised area of study offering the researcher flexible and opportunistic data collection strategies (i.e. members' associations in German football). Cases although often criticised as being descriptive, are necessarily so, as description helps establish case validity and rigour (Hines, 2018). Stake (1998) notes the importance of description to establish context, complexities and internal validity.

Data collection involved conducting semi-structured interviews with key individuals from the club board, the supervisory board and external stakeholders (Easterby, et al., 2008). Key respondents from HSV were selected for interview by applying a purposive sampling technique (Yin, 2014). The key respondents interviewed at HSV were:- 
- Key Respondent A, Managing Director of the fans department (has been Head of the Department since 1992 when it became an integral part of the football club).

- Key Respondent B, Elected board member on the supervisory board (has been a board member for 8 years and elected three times by HSV's members).

- Key Respondent C, Elected Supporter Director who sits on the club board (has been an elected Supporter Director for 6 years and was responsible for members' matters, also he was able to provide viewpoints from the club board).

The first series of questions set out to understand the micro and macro influences, which influenced the ownership structure of the football club (Reid \& Turbide, 2011). These sets of questions helped illustrate in further detail the circumstances leading up to increased fan involvement within HSV in the early 1990s and events leading to the imposed changes to their governance structure in 2014. The second set of questions were specifically included to understand how HSV structured their boards to implement their strategic plan and instigate good governance practices within the organisation. The final set of questions focused on asking the respondents to reflect on their internal governance practices in relation to overall performance, effectiveness and strategic capability. Several questions also focused on board composition, culture and inclusivity in terms of whether the boards had met their fans expectations on and off the pitch. The interviews were tape-recorded and transcribed to draw out important issues. These transcripts were then cross-referenced with analysis of secondary documents, which provided a chain of evidence that validated the findings (Miles \& Huberman, 2002; Veal \& Darcy, 2014).

\section{Secondary Documentary Analysis}

The case study accessed multiple sources of data in common with Yin (2014) who listed six sources of evidence for data collection in the case study protocol: documentation, archival 
records, interviews, direct observation, participant observation, and physical artefacts. Documentary analysis was undertaken to review governance information of HSV before the researchers visited the club to interview. These documents included web pages, annual accounts, board meeting minutes, policy documents and brochures. Data were then collated from these different documents sourced, to analyse the football clubs' performance, corporate governance strategies and overall management of the organization. This included HSV's written evidence submitted in response to the UK's Parliamentary Football Governance Inquiry in 2011 (Hamburger SV, 2011). Newspaper reports on issues of compliance and governance focusing on HSV and the Bundesliga were used as a secondary source. HSV's website and fan blogs were also studied. Finally, observations (direct and participant) were employed. The researchers became members of the football club and attended several supporters' AGM's and the recent EGM in May 2014.

\section{Data Analysis}

Key informant interviews, documents and participant observations have been analysed to make sense of emerging themes (Skinner, et al., 2014). The interview transcripts were typed and categorised electronically and the verbatim responses uploaded onto the NVivo software package for detailed analysis. Codes, categories and themes emerged from the analysis of the semi-structured interview transcripts and then cross-referenced with analysis of secondary documents (Braun \& Clarke, 2006). Following Corbin and Strauss's (2008) and Yin's (2014) approach to data analysis, the case has been written up as a holistic and comprehensive narrative. Rather than detailing every finding, the research provides a summary of the key findings using the pattern matching approach (Miles \& Huberman, 2002; Patton, 2002). However, in accordance with Yin (2014) all data has been adequately documented to allow other researchers to follow the procedural and decision trail. This methodological rigour provides 'auditability' to the final findings included in this article. The researchers immersed 
in the data from the case study through numerous readings of interview transcripts and secondary data, commenced data reduction through coding, eliciting emerging themes to interpret and make sense of the data before writing up the final analysis and discussion (Jones, 2014). Once data was analysed, the use of case study method allowed the researchers to classify, compare, and describe the findings in a more meaningful way for the reader. Fereday (2006) notes that case studies allow for the classification into categories and the identification of interrelationships between these categories from the data acquired.

\section{Case evidence: Hamburger SV (HSV)}

The findings from HSV illustrates a brief history of the club and documents the macro and micro influences on the formation of the fan department within HSV. The main themes identified from the literature were applied to describe and evaluate:- inclusivity, democratic governance structures, decision-making, raising alternative finance and responding to the numerous stakeholder demands. This case study focuses on HSV's governance practices from when the fan department became an integral part of HSV in August 1992 to the selling of 24.9\% stake of the club to private investors in July 2014.

\section{People Power}

HSV was formed in 1887 and upon the foundation of Germany's first professional league in 1963, were one of sixteen clubs invited to participate in the first season, and have competed in the top flight ever since. The club's golden age took place between 1976-1987, during which time they won three Bundesliga titles and reached two European Cup finals, winning one in 1983. However, by the late 1980 's the club had stagnated, and the low point came in the $1991 / 1992$ season, finishing in $11^{\text {th }}$ place. Key respondent A, Managing Director of the Fans Department explained that 'The foundation of the Supporters' Club was a reaction of fans who wanted to be more involved in the governance side of the club, in addition to following the club 
and watching matches. They wanted to participate in running the club and having their say. They wanted some sort of democratic aspect to their involvement. Fans wanted to make their thoughts known by being active members to stop the culture of the club as 'we decide what you do and you have to take it or leave it' (Personal Interview).'

Up until 2014, the club utilised and adhered to the 'one member, one vote' philosophy, with no 'spin off' or external investment within the football club. As previously, discussed earlier in this article, HSV were in the minority in relation to their governance structure decision to remain as a $100 \%$ members' association. The 'one member, one vote' was operationalised via each member paying a yearly membership fee and through these subscriptions, all members have an equal say/vote in the football club. The fan department have proactively and consistently focused on increasing and maintaining their membership since their formation in 1992. HSV are proud of their membership numbers and have managed to exceed average home attendance $(75,000$ members, average home attendance 55,000). As key respondent $\mathrm{B}$, exboard director of the supervisory board recalled 'the idea was to bring the fans into the club so we could change the clubs' political ideology. On one hand we are seen as a service to organise fans affairs, i.e. away trips, sports clubs that sort of thing and then on the other hand we are seen as a political organisation representing fans views on how the club was being run (Personal Interview).' Interestingly, the core of the most politically motivated members at HSV felt, during the time of the researchers visit, that the ever-growing number of members had resulted in the dilution of the fan department's main philosophical stance. They felt that fans were joining as members to the club to receive match day benefits rather than contribute to the political cause of the fan department. Something, that came to the fore during the Extraordinary General Meeting (EGM) organised in May 2014. However, for many years the increasing membership enabled the fan department to be financially sufficient and with the sheer numbers 
created a feeling of political power over the club board. As key respondent A stated 'the club board know that if they make mistakes they have to be accountable to 75,000 members'.

For over sixteen years HSV fans witnessed several of their club's competitors restructuring to attract private investment and become more competitive on the pitch, the majority voted against their club following suit and a similar path, until 2014. During this time, HSV fans were admired for wanting to continue with their members' association structured and were respected for signalling laudably that they were more interested in the club being managed properly than pursuing sporting excellence on the pitch at any cost.

\section{Governance structures}

HSV operate with two main boards, namely, a club board with twelve directors elected on the supervisory board and up to five directors on the club board. Elected directors of the supervisory board have a term of four years but can have their position terminated within this time if they are not deemed to be fulfilling their role properly. Key respondent A, highlighted that the football club also instigated a change in policy to streamline and protect their election processes. He said 'our directors serve a maximum of four years before re-election. Every two years we elect half of them again. It used to be one election every four years but we decided against this because of the realisation that HSV could have eleven new directors with no experience in the boardroom to draw upon (Personal Interview).' This change of election process enabled the club to keep their boards fresh by regularly evolving key personnel.

HSV have several smaller boards who are responsible for different operational activities of the football club. The supervisory board and club board meet every quarter for strategic planning unless an EGM is called. The club board are empowered and trusted to run the day-to-day operations of the club with minimal intervention. They are able to identify and purchase players within an agreed maximum spend per player. Anything over this set spending cap has to be 
presented to the supervisory board in order for a democratic decision to be made and meets the financially sustainable wishes of the club's members.

The HSV's internal governance structures are illustrated below.

Figure 1 - The HSV Structure

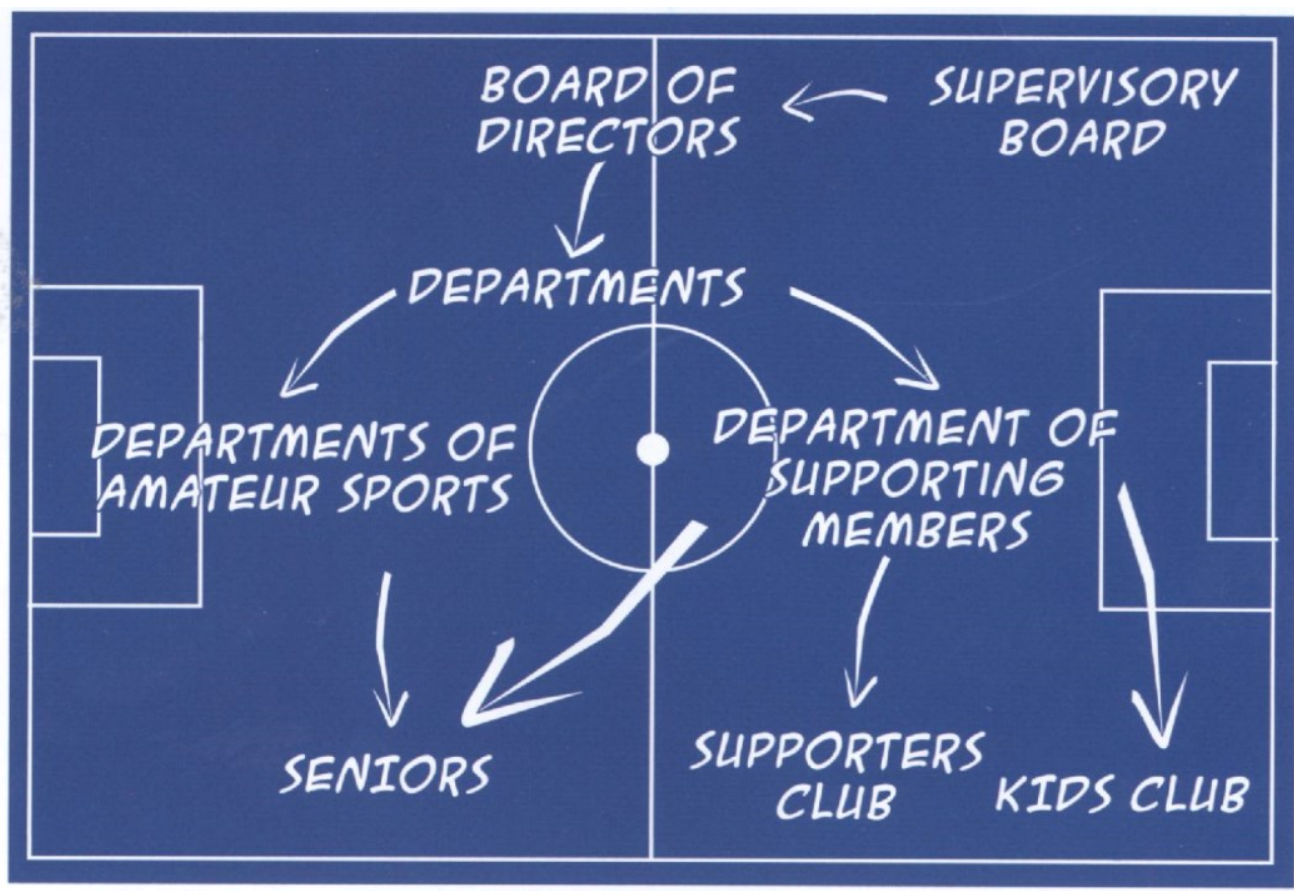

Supervisory Board

Board of Directors 

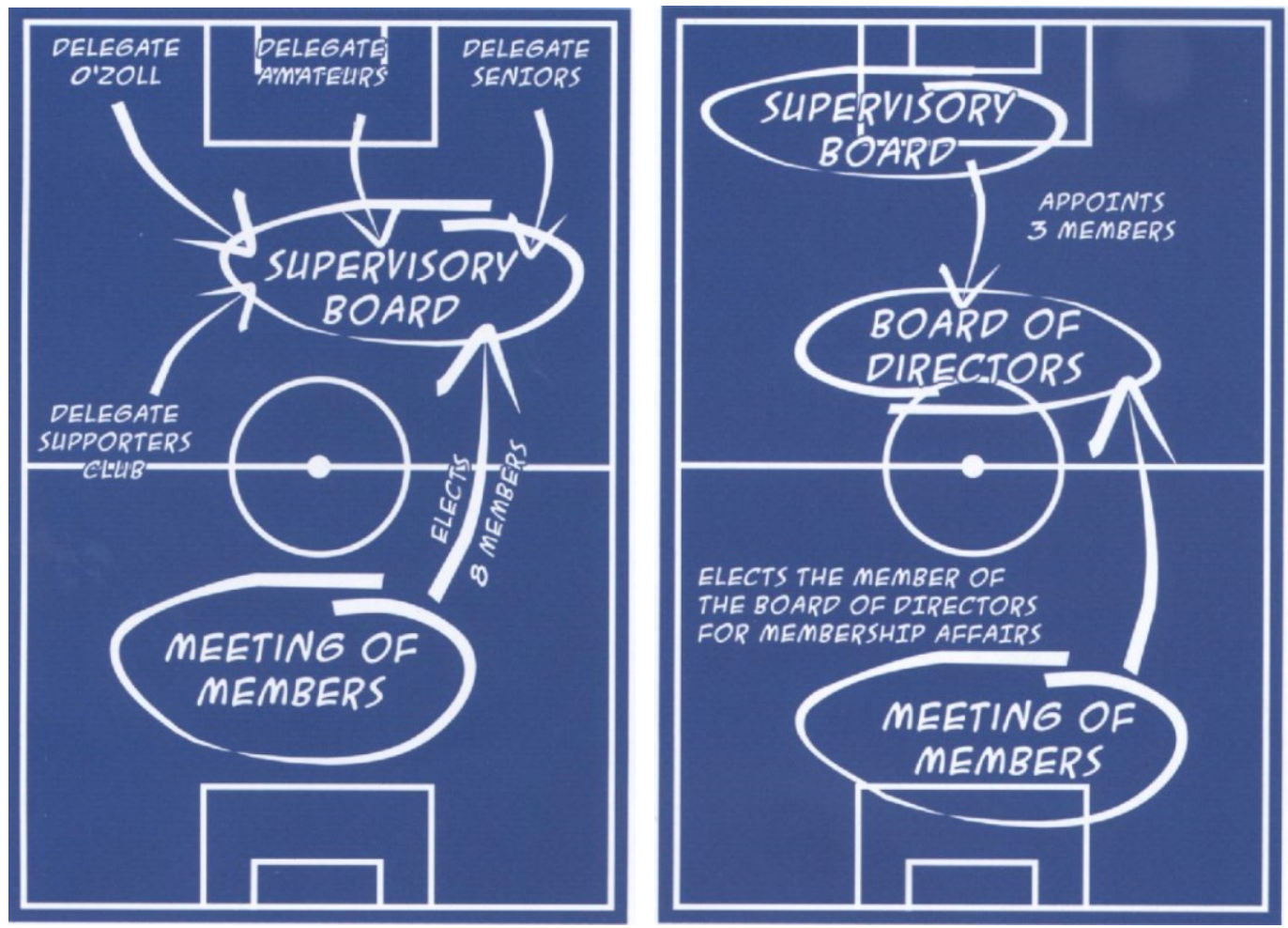

Tensions between the boards inevitably occur but as key respondent A notes 'there will always be frictions between the club board and the supervisory board but over the years we have found common ground to overcome these disagreements for the benefit of the football club. The club board continually question the club's structure in order to boost the playing budget and bring in private investment. The supervisory board continually remind the club board of the core philosophy of the members by stating the future sustainability of the club is more important than on pitch success (Personal Interview).'

The supervisory board may call an EGM if they are unhappy or concerned about the strategic effectiveness of the board of directors. Furthermore, if the club board wishes to change any of the statutes or working policies within the football business they need to seek approval from the honorary board as well as the supervisory board. Key respondent C, Director of Membership Affairs recollects when tensions were high between the two main boards in 2005, 'the club board wanted to challenge and ultimately change the structure within the football 
club to gain more private investment to spend on players. On the request of the club board, the club opened this proposal out to the members to utilise their 'one member, one vote'. The members voted against the proposal with the majority happy to remain with the current structure even if this affected the football team's on-pitch performances (Personal Interview).' A similar challenge against the ownership structure of the club occurred again during the summer of 2014, which is detailed later on in this case.

The supervisory board directors are unpaid and rely on volunteers but the club board directors are paid a salary and are employed as full time employees. While the first are elected as mentioned above, the members of the board of directors are appointed by the supervisory board. There is one exception to this rule, which relates to the Director of Membership Affairs. Directors who have volunteered to work on the supervisory board were either retired, employed or self-employed. The main limitation to voluntary board members was the inability to dedicate enough time to the job due to commitments from their paid work or activities away from the club. These extra-curricular activities also made meeting up on a regular basis difficult due to time constraints. As key respondent B highlighted if you work on the supervisory board you need to be able to honour a part time unpaid job within the club, which requires commitment, self-motivation and a real passion for HSV (Personal Interview).' The main benefits highlighted were the diverse range of skills the club has received from the volunteers who have worked for the club. Furthermore, the club had successfully recruited 'new blood' onto their board (primarily due to the club's nomination/election process) who had been able to meet the evolving challenges as the business grew. Key respondent A stated that the main advantage of having an independent voluntary supervisory board is that they are far more direct in their approach than they would be if they were paid full time members of staff (Personal Interview).'

\section{Source alternative revenue streams}


The need to identify and source alternative revenue streams was one of the major strategic priorities for HSV operating as a non-profit football club. HSV have been consistently one of the top ten most successful European football clubs in commercial revenue generation over the past decade. Sponsors and commercial businesses are keen to do business with HSV due to the large number of members these businesses can access. HSV compete in the highest league in Germany (Bundesliga 1) and receive global media interest. The potential for sponsors of the club to tap into a global market is also an attractive proposition to them. Their fluctuating league positions have meant that the club have not been able to compete in the lucrative European competitions, resulting in a drop in TV and gate receipt income in recent seasons. Match day revenue represented the most important revenue stream to the football business with $37 \%$ coming from this source (Deloitte, 2014). HSV's commercial revenues are supported by an extended deal with shirt sponsor Emirates, which runs until 2019, bringing in $€ 7.5 \mathrm{~m}$ per year. Furthermore, HSV secured a deal with a local billionaire to boost the club's player budget. Key respondent B explains that the deal was 'for $€ 15$ million Kühne Logistics gets the transfer rights of $30 \%$ of five players. So that means if we sell a player for $€ 20$ million then he will get €6 million back as his return on his investment (Personal Interview).' Kühne bought further shares in HSV when the stadium naming rights deal with Imtech expired in July 2015. The stadium reverted back to its original name of 'Volksparkstadion' appeasing the club's members and making the local billionaire a popular shareholder with the fan base. HSV's commercial operations have underpinned the club's alternative revenue strategy and have remained resilient to the club's on-pitch difficulties.

\section{External stakeholder pressure}

During the 2013/2014 season the mutual philosophy of the football club came under internal scrutiny and intense pressure once more. In late 2013, several wealthy HSV members announced that they were willing to invest to boost the playing budget. In return, they stipulated 
that they wanted the professional football department to be 'spun-off' and were sold $24.9 \%$ of its equity capital. As key respondent $\mathrm{C}$ explained 'Their reasoning centred on HSV reforming to a more professional structure to become more competitive. Their frustrations had built up over several seasons of poor League finishes. Obviously this proposal of investment and their demands did not embrace the democratic culture within the club (Personal Interview).' However, events were to unfold, boosted by a high profile and sophisticated media campaign to rally support amongst the members. The campaign soon gathered momentum to put pressure on the mutual structure of the club, the removal of what they saw as ineffective governance structures and for the club to 'spin-off' their professional football department into a public limited company similar to their rivals Bayern Munich.

Opinion was divided once more and politically active members loyal to the (e.V.) structure launched their own media campaign entitled - HSV Not For Sale (Shave, 2013). On the pitch, HSV narrowly escaped relegation with a 0-0 draw at home and a 1-1 draw away against Greuther Fuerth during their final relegation play-off game. In May 2014, an Extraordinary General Meeting (EGM) was called for members to vote on the proposed 'spin-off' structure, the intended sale of $24.9 \%$ share of the professional football department to private investors (anything equalling or over $25 \%$ entitles special minority rights for private investors) and restructuring of the members' associations statutes. A total of $86.9 \%$ of the 9,702 participating members voted in favour and the re-structure was actioned.

\section{Discussion}

HSV demonstrated that a mutually owned football club could survive at the highest level of domestic competition and attract adequate commercial revenue streams without relying on private investment. The large numbers of members acted as an unintentional audit function with an unconscious influence on the club board to make sustainable decisions for the interests 
of all parties involved in the club. HSV have also showed that it is possible to manage a large membership and act in a transparent and accountable manner. For a considerable length of time the fans department were successful in educating their membership to their core philosophy (Puyvelde et al., 2012). HSV should be commended for remaining as a members' association for many years after the ' $50+1$ ' ruling was introduced. Despite fierce internal and external environmental challenges to their chosen governance structure, they were able, in most cases, to defend and diffuse these calls to change. With the historic changes to HSV's structure in 2014 , the parent club still have the largest supporters' club in the country with over 70,000 members.

There were clear disadvantages in terms of the difficulty of operating under an inclusive and transparent business model (Perilleux, et al., 2012). The fan department at HSV highlighted the huge task involved in continuing to recruit members, raise membership fees and the resources required to maintain and service the large memberships involved. HSV particularly commented on their fans continuous need to be informed on the club's business activities, which resulted in up to five hundred emails a day. Overly bureaucratic decision making was also identified as one of the main disadvantages of instilling democracy and inclusivity in the boardroom (Steinberg, 2010). HSV's board structures acknowledged the difficulty of managing internal decision-making processes, coupled with the integration of the club's stakeholder interests (Balduck, et al., 2010; Callen, et al., 2010; Murdock, 2004). These difficulties resulted in slow decision-making processes and in some instances the catalyst for internal politics. Furthermore, there were continuous tensions between fan ambitions and members' associations' principles, which inevitably fuelled the demise of the $100 \%$ members' association structure at HSV in 2014 (Ferkins \& Shilbury, 2015).

What has become apparent from these continued tensions at HSV and the governance literature relating to mutuality is the constant balance between financial sustainability and on-pitch 
performance (Dietl \& Franck, 2008). There was, however, clear evidence to support the literature in terms of achieving inclusivity and increasing stakeholder involvement, whilst operating as a members' association (Brown, 2002; Harris \& Houlihan, 2014). Seemingly, the '50+1' rule has balanced the differing stakeholder interests through a compromised hybrid business model, by meeting the members needs whilst attracting private investment to boost the playing budget and maintain competitive advantage (Cornforth, 2003). Aligned with stakeholder theory, the '50+1' rule can, if implemented correctly, satisfy multiple stakeholder demands. The case study approach utilised for this research enabled exploration of this under theorised topic (Hines, 2018). The findings add further empirical evidence to the governance literature pertaining to football and the debate surrounding the future sustainability of members' associations.

\section{Conclusion}

A consideration of the nonprofit governance literature as well as selected aspects of organisation theory highlights relevant theoretical influences for footballing contexts (Dimitropoulos \& Tsagkanos, 2012; Ferkins \& Shilbury, 2015). These influences focus on concerns around ownership and control of organisations and probe issues such as manager dominance and control of the shareholder interests (Steinberg, 2010). National sport organisations too are grappling with the growing dominance of management involvement in governance, signalling a potential retreat by volunteer Board members who have traditionally been elected to protect the interests of membership. If, as the literature suggests, volunteer Board members are ceding control to paid professionals, this potentially leaves the interests of the membership-at-large (fans) unattended. The nonprofit governance literature has also helped identify the additional complexity faced by nonprofit Boards in achieving organisational outcomes (Brown, et al., 2011). 
Regardless of the ownership structure adopted, the pressure to pursue success on the field of play builds in a propensity to gamble on player expenditure at any football club (Wilson, et al., 2013). However, what underpins a members' association is the belief that football supporters have a primary concern to preserve their club and to ensure the club is beneficial for the community (Harris \& Houlihan, 2014). Therefore, academics and commentators in favour of mutually owned football clubs believe that they are more likely to be more diligent guardians of their club's future than benevolent private owners are (Hamil, et al., 2010). As a result, members' associations' offer an opportunity for organised collective action and ownership, which is increasingly rare in an economy where the imposition of market mechanisms on every area of economic and social activity is becoming more pronounced (Puyvelde, et al., 2012). Despite the evident pros and cons of this model, it remains deeply rooted within German business and society. Inevitably, there will be more pressure placed towards members' associations and their future within German professional football over the next few years.

Recommended further research should continue to examine the correlation between governance, financial performance and sporting performance in football and other sports. In particular, research should focus on enhancing our understanding of German football and their differing structures. Further qualitative studies should focus on the purest form of a members' association (e.V.), the hybrid model (KG) and the shareholder model (AG), which are in operation in Germany today. Borussia Dortmund and Werder Bremen are both examples of clubs who operate under a hybrid company form (KG structure) with FC Bayern Munich being the only German club to be listed on the Stock Exchange. These particular cases will add further evidence, to support or not, the growing notion that the hybrid model could be found to be the ideal structure for the footballing industry (Hassan, et al., 2010). Findings from such studies would contribute greatly to the continuing commercial and academic rhetoric around ownership, governance, performance and sustainability. 


\section{References}

Acero, I., Serrano, R., \& Dimitropoulos, P. (2017). Ownership Structure and Financial Performance in European Football, Corporate Governance: The International Journal of Business in Society, 17(3).

Agrawal, A., \& Knoeber, C. R. (1996). Firm Performance and Mechanisms to Control Agency Problems between Managers and Shareholders, The Journal of Financial and Quantitative Analysis, 31(3), 377-397.

Anheier, H. K., Katz, H., Mosley, J., \& Hasenfeld, Y. (2003b). Positioning for the Future: The Nonprofit and Community Sector in Greater Los Angeles, Los Angeles, CA: UCLA School of Public Policy and Social Research.

Babiak, K, M. \& Willem, (2017). Sage Sport Management Handbook, Cited in Hoye, R. and Parent, M. (2017) The Sage Handbook of sport management. Sage; London.

Balduck, A., Van Rossem, A., \& Buelens, M. (2010). Identifying competencies of board members of community sports clubs, Nonprofit and Voluntary Sector Quarterly, 39(2), 213 235.

Barbetta, G. P., Turati, G., \& Zago, A. (2001). On the Impact of ownership and Hospital Efficiency in Italy, Conference Paper, Pavia University, $5^{\text {th }}-6^{\text {th }}$ October.

Braun, V. \& Clarke, V. (2006). Using Thematic Analysis in Psychology, Qualitative Research in Psychology, 3, 77-101.

Brown, W.A. (2002). Inclusive Governance Practices in Nonprofit Organisations and Implications for Practice. Nonprofit Management \& Leadership, 12(4), 369-385.

Brown, W., Hillman, A., \& Okun, M.A. (2011). Factors that Influence Monitoring and Resource Provision Among Nonprofit Board Members, Nonprofit and Voluntary Sector Quarterly, 41(1), 145-156.

Czarnitzki, D., \& Stadtmann, G. (2002). Uncertainty of outcome versus reputation: Empirical evidence for the First German Football Division, Empirical Economics, 27(1), 101-112. 
Callen, J., Klein, A., \& Tinkelman, D. (2010). The contextual impact of nonprofit board composition and structure on organizational performance: Agency and resource dependence perspectives, Voluntas, 21(1), 101-125.

Coalter, F. (2013). Sport for Development what game are we playing? London:Routledge.

Conn, D. (2012). German model bangs the drum for club, country and the people's game, The Guardian, http://www.theguardian.com/football/david-conn-inside-sport$\underline{\text { blog/2012/dec/01/german-fan-owned-clubs-bundesliga }}$

Conn, D. (2012). Borussia Dortmund boss attacks Premier League's oligarch owners, The Guardian, http://www.theguardian.com/football/2012/dec/02/borussia-dortmund-premierleague

Corbin, J., \& Strauss, A. (2008). Basics of Qualitative Research, 3rd Edition, Thousand Oaks, CA:SAGE.

Cornforth, C. (2003). The governance of public and non-profit organisations: What do boards do? London, Routledge.

Deloitte (2014). Annual Review of Football Finance, Manchester.

Dietl, H., \& Franck, E. (2007b). How do the peculiarities of German Football Governance affect the abilities of clubs to create and capture value? In P. Rodriguez, S. Kesenne, \& J. Garcia (Eds), Governance and competition in professional sports leagues, 87-107, Oviedo:Oviedo Press.

Dietl, H., \& Franck, E. (2008). Overinvestment in team sports leagues - a contest theory model, Scottish Journal of Political Economy, 55(3), 353-368.

Dimitropoulos, P., \& Tsagkanos, A. (2012). Financial Performance and Corporate Governance in the European Football Industry, International Journal of Sport Finance, 7(4), 280-308.

Easterby-Smith, M., Thorpe, R., \& Jackson, P. (2008). Management Research, $3^{\text {rd }}$ Edition, London:SAGE.

Eisenhardt, K. M., \& Graebner, M. E. (2007). Theory building from cases: Opportunities and challenges, Academy of Management Journal, 50, 25-32. 
Enjolras, B. (2009). A governance-structure approach to voluntary organizations. Nonprofit and Voluntary Sector Quarterly, 38(5), 761-783.

Esteve, M., Di Lorenzo, F., Inglés, E., \& Puig, N. (2011). Empirical Evidence of Stakeholder Management in Sports Clubs: The Impact of the Board of Directors, European Sport Management Quarterly, 11(4), 423-440.

Fama, E.R., \& Jensen, M.C. (1983). Separation of Ownership and Control, Journal of Law and Economics, 26, 301-325.

Fereday, J. (2006). Demonstrating Rigor using Thematic Analysis: A Hybrid Approach of Inductive and Deductive Coding and Thematic Development, International Journal of Qualitative Methods, 8(1), 80-92.

Ferkins, L., \& Shilbury, D. (2010). Developing board strategic capability in sport organisations: the national-regional governing relationship, Sport Management Review, 13(3), 235-254.

Ferkins, L., \& Shilbury, D. (2015). The Stakeholder Dilemma in Sport Governance: Toward the Notion of "Stake owner", Journal of Sport Management, 29(1), 93-108.

Franck, E. (1999). Zur Organisation von Sportligen, DBW-Die Betriebswirtschaft, 59(4), 531-547.

Franck, E. (2000). Die Verfassungswahl bei Fußball clubs unter besonderer Beachtung der spezifischen Produktionsstruktur des Teamsports, in M.P. Büch (Hrsg.), Märkte und Organisationen im Sport, Schordorf:Hofmann, 11-26.

Franck, E. (2010). Private Firm, Public Corporation or Members' Association Governance Structures in European Football. International Journal of Sport Finance, 5(2), 108-127.

Franck, E., \& Dietl, H.M. (2007). Governance Failure and Financial Crisis in German Football, Journal of Sports Economics, 8(6), 662-669.

Franck, E., \& Müller, J.C. (1998) Kapitalgesellschaften im bezahlten Fußall, Zeitschrift für Betriebswirtschaft, 2, p. 121-141 
Freeman, R. E. (1984). Strategic Management: A Stakeholder Approach, Boston:Pitman Publishing, 24-32.

Hassan, D., \& Hamil, S. (2010). Models of Football Governance and Management in International Sport, Soccer \& Society, 11(4), 343-353.

Hamburger SV (2007 -2014). Hamburger SV: Annual Report and Accounts.

Hamburger SV (2011). Written evidence to the Parliamentary Inquiry into Football Governance, Retrieved from

http://www.publications.parliament.uk/pa/cm201012/cmselect/cmcumeds/792/792vw70.htm

Hamil, S., Walters, G., \& Watson, L. (2010). The Model of Governance at FC Barcelona:

Balancing Member Democracy, Commercial Strategy, Corporate Social Responsibility and Sporting Performance, Soccer \& Society, 11(4), 475-504.

Harris, S., \& Houlihan, B. (2014). Delivery networks and community sport in England, International Journal of public sector management, 27(2), 113-127.

Herman, R., \& Renz, D. (2008). Advancing nonprofit organizational effectiveness research and theory: Nine theses. Nonprofit Management and Leadership, 18(4), 399-415.

Hill, C.W.L. \& Jones, T.M. (1992). Stakeholder-Agency Theory, Journal of Management Studies, 29, 131-154.

Hines, T. (2018). Advances in Case Study Research, London:YNS.

Hutton, W. (2007). The Writing on the Wall: China and the West in the 21st Century, London:Vintage.

Jensen, M. C., \& Heckling, W. H. (1976). Theory of the firm: Managerial behaviour, agency costs and ownership structure, Journal of Financial Economics, 3(4), 305-360.

Jones, I. (2014). Research Methods for Sports Studies, 3rd edition, London:Routledge.

Lago, U., Simmons, R., \& Szymanski, S. (2006). The Financial Crisis in European Football, Journal of Sports Economics, 7(1), 3-12.

Lammert, J., Hovemann, G., Wieschemann, C. \& Richter, F. (2009). Das

Spannungsverhältnis von Finanzierungsinteressen und der Vermeidung eines beherrschenden 
Einflusses im deutschen Profi-Fußball - Notwendigkeit und Vorschläge zur Modifizierung der derzeitigen Regulation. Sport und Gesellschaft, 6(3), 203-233.

Leete, L. (2000). Wage equity and employee motivation in Nonprofit and for-profit organisations, Journal of Economic Behaviour and Organization, 43, 423-446.

Littkemann, J., Brast, C., \& Stübinger, T. (2003). Neuregelung der Prüfungsvorschriften für die Fußball-Bundesliga, StuB-Steuern und Bilanzen, 4(14), 635-642.

McDonald, H., \& Sherry, E. (2010). Evaluating a Sport Club Based Performance: A Customer Perspective, Journal of Sport Management, 24(5), 524-543.

Miles, M., \& Huberman, A. (2002). The Qualitative Research Companion, London:SAGE. Murdock, A. (2004). Stakeholder theory, partnerships and alliances in the health care sector of the UK and Scotland. International Public Management Review, 5(1), 21-39.

Patton, M. Q. (1990). Qualitative Evaluation and Research Methods, California:SAGE.

Pergola, T.M., \& Joseph, G.W. (2011). Corporate Governance and Board Equity Ownership, Corporate Governance, 11(2), 184-199.

Perilleux, A., Hudon, M., \& Bloy, E. (2012). Surplus Distribution in Microfinance:

Differences Among Cooperative, Nonprofit and Shareholder Forms of Ownership, Nonprofit and Voluntary Sector Quarterly, 41(3), 386-404.

Pilz, G. Bahn, S., Klose, A., Schwarzer, S., \& Woelki, F. (2006). Wandlung des uschauerverhaltens im Profifußball, Bundesinstitut fuer Sportwissenschaft, Bonn:Hoffman.

Puyvelde, S.V., Caers, R., Du Bois, C., \& Jegers, M. (2012). The Governance of Nonprofit Organizations: Integrating Agency Theory with Stakeholder and Stewardship Theories, Nonprofit and Voluntary Sector Quarterly, 41(3), 431-451.

Reid, W., \& Turbide, J. (2011). Board/Staff Relationships in a Growth Crisis: Implications for Nonprofit Governance, Nonprofit and Voluntary Sector Quarterly, 41(1), 82-99.

Senaux, B. (2008). A stakeholder approach to football club governance. International Journal of Sport Management and Marketing, 4(1), 4-17. 
Shave, B. (2013). HSV - Not for Sale, Retrieved from http://www.supportersdirect.org/news-article/hsv-not-for-sale

Skinner, J., Edwards, A., \& Corbett, B. (2015). Research Methods for Sport Management, London: Routledge.

Stake, R. (1998). Case Studies in: Denzin \& Lincoln. (eds.): Strategies of Qualitative Inquiry, Thousand Oaks:London, New Delhi:Sage.

Steinberg, R. (2010). Principal Agent Theory and Nonprofit Accountability, in K.J. Hopt \& T. Von Hippel (Eds), Comparative Corporate Governance of Nonprofit Organisations 73125, Cambridge:Cambridge University Press

Sternberg, E. (1997). The defects of stakeholder theory, Corporate Governance, an international review, 5(1), 3-10.

Tschirhart, M. (2006). Nonprofit Membership Associations, in: Powell, W. W., \& Steinberg, R. (Hrsg.): The Nonprofit Sector - A Research Handbook, 2nd Edition, New Haven:Yale University Press.

Vidovich, L., \& Currie, J. (2012). Governance Networks - Interlocking Directorships of Corporate and Nonprofit Boards, Nonprofit Management \& Leadership, 22(4), 507-523.

Wagner, G. (1999). Bundesliga Going Public: Traumpaß oder Eigentor?, NZG 11/1999, 469-478.

Ward, S., Scanlon, T., \& Hines, A. (2013). Mutuality Ownership Form in Professional Sports: Football, Nonprofit \& Voluntary Sector Quarterly, 42(4), 763-780.

Weitzner, T., \& Peridis, T. (2011). Corporate Governance as Part of the Strategic Process: Rethinking the Role of the Board, Journal of Business Ethics, 102(1), 33-42.

Weiler, S. (2007). Multi-Club Ownership-Regelungen im Deutschen Profifußball - Eine Kritische Bestandsaufnahme, SpuRt - Zeitschrift für Sport und Recht, 14(4), 133-139.

Wheeler, D., \& Sillanpaa, M. (1997). The Stakeholder Corporation: A Blueprint for maximising stakeholder value, London:Pitman.

Wilkesmann, U., \& Blutner, D. (2002). Going Public: The Organizational Restructuring of German Football Clubs, Soccer and Society, 3(2), 19-37. 
Wilson, R., Plumley, D., \& Ramchandani, G. (2013). The relationship between ownership structure and club performance in the English Premier League, Sport, Business and Management: An International Journal, 3(1), 19-36.

Veal, A. J. \& Darcy, S. (2014). Research Methods in Sport Studies and Sport Management: A Practical Guide, London: Routledge.

Yin, R. (2014). Case Study Research: Design and Methods, $5^{\text {th }}$ Edition, Thousand Oaks, CA:SAGE.

Ziebs, A. (2004) Ist sportlicher Erfolg kaüflich? Eine diskriminanzanalytische Untersuchung der zentralen Erfolgsfaktoren in der Fußall-Bundesliga, Sport und Gesellschaft, Sport and Society, 1(1), 30-49 